\title{
E-Business as an Entrepreneur's Creativity Strategy
}

\author{
Rizki Zulfikar ${ }^{1}$, and Suci Rahayu Rahmatillah ${ }^{2}$ \\ \{rizki.zulfikar@email.unikom.ac.id ${ }^{1}$, sucirahayura@mahasiswa.unikom.ac.id ${ }^{2}$ \} \\ ${ }^{1}$ Departemen Manajemen, Universitas Komputer Indonesia, Indonesia, ${ }^{2}$ Departemen Akuntansi, \\ Universitas Komputer Indonesia, Indonesia
}

\begin{abstract}
This paper aims to analyze entrepreneurs who are using E-Business in developing their business creativity strategies. The research method used in this paper is Descriptive Method, which describes and compares social problems based on facts, theories, and accurate reference sources. The results of this paper explain that E-business has an important role in improving the quality and performance of a company. Because EBusiness can be used as a strategy in tight competition by maximizing operations and minimizing the company's long-term risks, of course, this needs to be done by entrepreneurs who want to make the company superior and realize a good image in the modern era. E-Business also has real-time information about each of the products that have already offered the data in exchange system, which is very effective and efficient for the consumers or the suppliers who need more information about the product that they want.
\end{abstract}

Keywords: E-Business, Entrepreneur.

\section{Introduction}

E-Business is a business opportunity for offline companies as an effort to increase their online sales and to respond the intense competition from E-Commerce companies [1]. K. S. Al Omoush stated that the use of E-Business Technology whose innovation has a significant impact on longterm success [2]. E. M. de Souza stated that the positive performance of E-Business companies is influenced by the ability to build good customer relationships, partnerships, and in achieving the proportion of income [3]. Furthermore, web-based technology enables companies to have accurate product information exchanges in real-time and on time as well as demanding costs with upstream suppliers and downstream customers, thus enabling companies to better manage their product margins [4]. According to Dr. Ir. Eddy Soeryanto Soegoto, creativity is an inherent characteristic of someone who is able to imagine and have the initiative in producing new products or services [5].

E-Business technology can improve operational management because through E-Business technology, companies provide accurate and timely information and also provide freedom in management to improve their talents. For example, Indonesian Cortifiel clothing manufacturer stated that Spandex which uses web-based media tools such as linkedIn, Facebook, and Twitter to recruit operational talent managerial in accordance with the profile in designing his talent base [6]. Research conducted by F. Karimi explained that E-Business technology has a positive effect on operational competencies, for example Air Canada, the largest airline in Canada, was invested in 2007 in web-based technology to make the first airline to offer customers online 
boarding passes and self-service applications to save costs (increase gross margins) and increase their operational excellence [7].

In contrast to previous research, J. Benitez, et al., Stated that E-Business has a beneficial effect on companies such as Actualidad Economica which is a leading business magazine company in France that develops the company's annual ranking on sales and innovation to compile databases with rich information thus becoming the most admired company in Spain [8]. S. Aral, stated that E-Business technology could also be used to access more knowledge; the example is manufacturing as a learning medium so that it can increase employee productivity and talent [9]. Implementing the E-Business strategy in improving business performance is not only carried out by large entrepreneurs but has begun to dominate the entrepreneurship of MSMEs, such as UMKM Yogyakarta Trooper, UMKM with a stakeholder model (consumers, business owners, vendors and stakeholders' interests) [10]. The purpose of this paper is to analyze entrepreneurs who use E-Business in developing their business creativity strategies to produce optimal and superior operational activities.

\section{Method}

The research method used in this paper is the Descriptive Method, which describes and compares social problems based on facts, theories, and accurate source references with previous research on the role of E-Business in the company's operational strategy to create entrepreneurs who have a superior company with a positive image. The comparison was carried out at local and international companies that have used E-Business technology so that it illustrates how much impact will be obtained from E-Business in terms of operational, profit, and image.

\section{Results and Discussion}

The entrepreneur's strategy to improve their company is carried out in various ways, including the use of today's technology which is often called E-Business [11]. This has been proven to be a powerful web-based technology in attracting consumers to the products or services offered by companies that use it such as Amazon.com, Alibaba.com, and Shopee who have used EBusiness in the field of sales and Smart money that uses E-Business as a service in the field of finance or banking. Of course this makes it easy for consumers to receive the latest information about products or services provided without having to come directly to their company, providing many benefits in terms of time and efficiency of the transactions that are carried out.

The role of E-Business in operational and marketing strategies also impacts the income that will be obtained by the company. Therefore, taking advantage of E-Business to compete may become superior to others [12]. Figure 1 shows Raphael Amit and Christoph Zott explaining the factors of creating quality E-Business values, including the efficiency of transactions which can improve the quality of information on a product. For example, companies that operate virtually will reduce information about bargaining that is traditionally done by traditional customers.

Complementary is intended for companies to be able to complete the service and the availability of goods both vertical (post-journal) or horizontal (one-stop shopping) related to the transaction. As is the case with Ebooker, an online travel site that provides weather information, exchange rates, immunization health services related to increase the value of core products in the form of airline tickets and vacation packages so as to provide comfort for its customers. Lock-in is intended to ensure that customers do not change their trust to competitors, this can 
be done by conducting a loyalty program: in the form of awards, bonuses that can increase satisfaction and trust in the company that they have. For example, Novelty or Innovation on products, services, production, and marketing are carried out by Ebay who innovate by trading low-value goods so that they are different from their competitors. Therefore, entrepreneurs would try to understand the strategic management business model framework in entrepreneurship because if the entrepreneur does not do this it will damage the industrial structure and pose a serious threat to the company's fundamentals

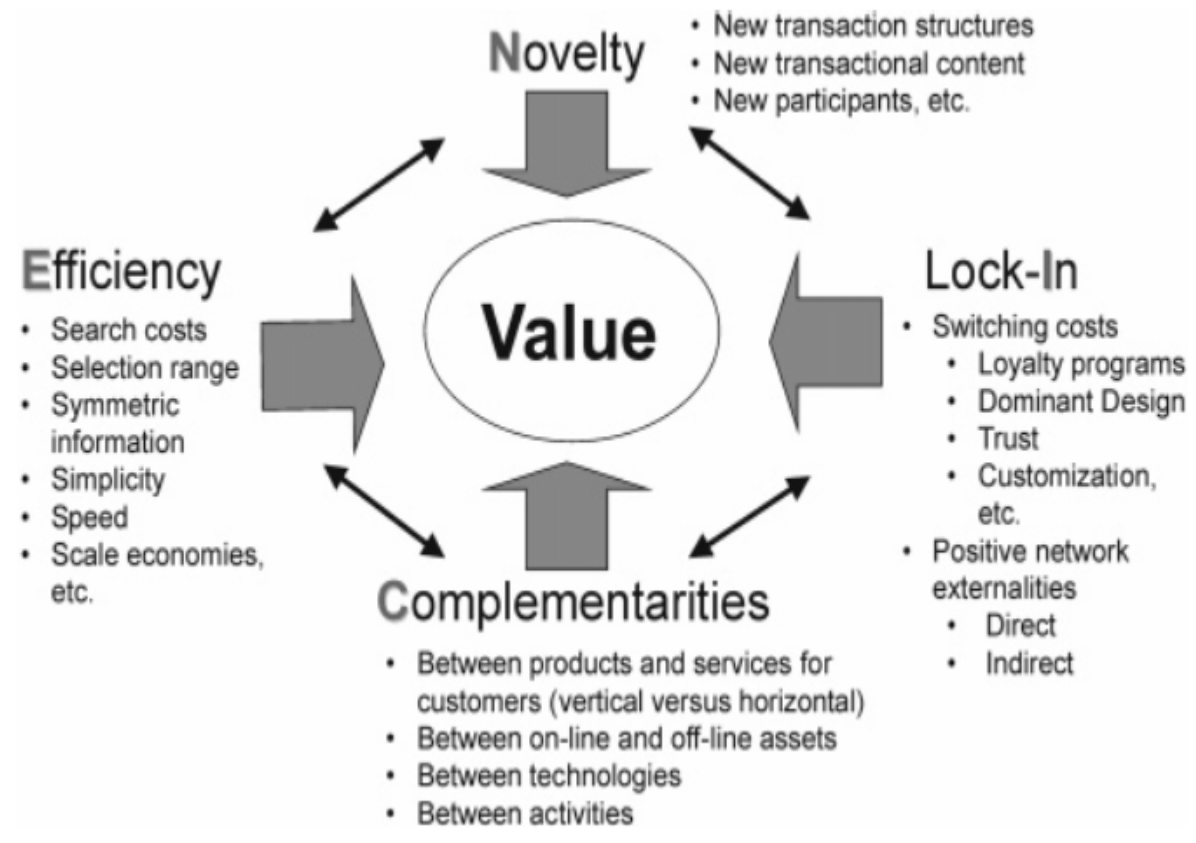

Fig. 1. Sources of value creation in E-Business

Here are companies that implement E-Business in their business management strategies and have a positive image:

1. Amazon.com

Figure 2. The Amazon.com's design has simple elements and uses colors that are not too contrasting to the eyes, this is done so that customers who access their E-Business become comfortable. 


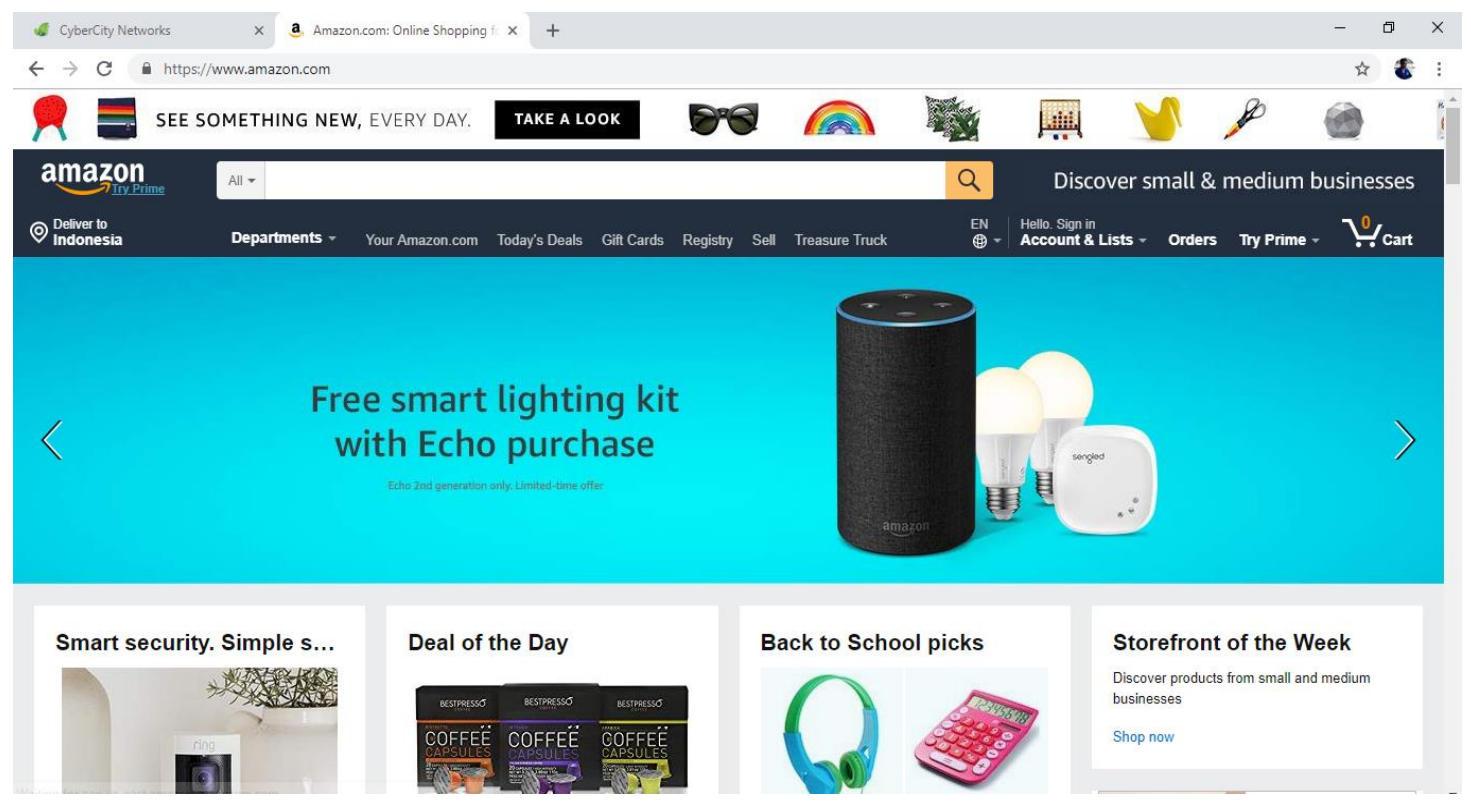

Fig. 2. Form Design. This figure was adopted from amazon.com on July 17, 2018.

Figure 3. When viewed from the picture above, Amazon.com's strategy in its E-Business is to provide a large-scale product that provides all the needs of the community from all aspects that cover the letters from $\mathrm{A}$ to $\mathrm{Z}$ and expect all customers to feel comfortable and satisfied in their transaction. According to Pramisti, the usage of E-business on Amazon.com has achieved a profit of \$136 Milion, a margin of 1,74\% and has a total of 341.400 employed in 2016.

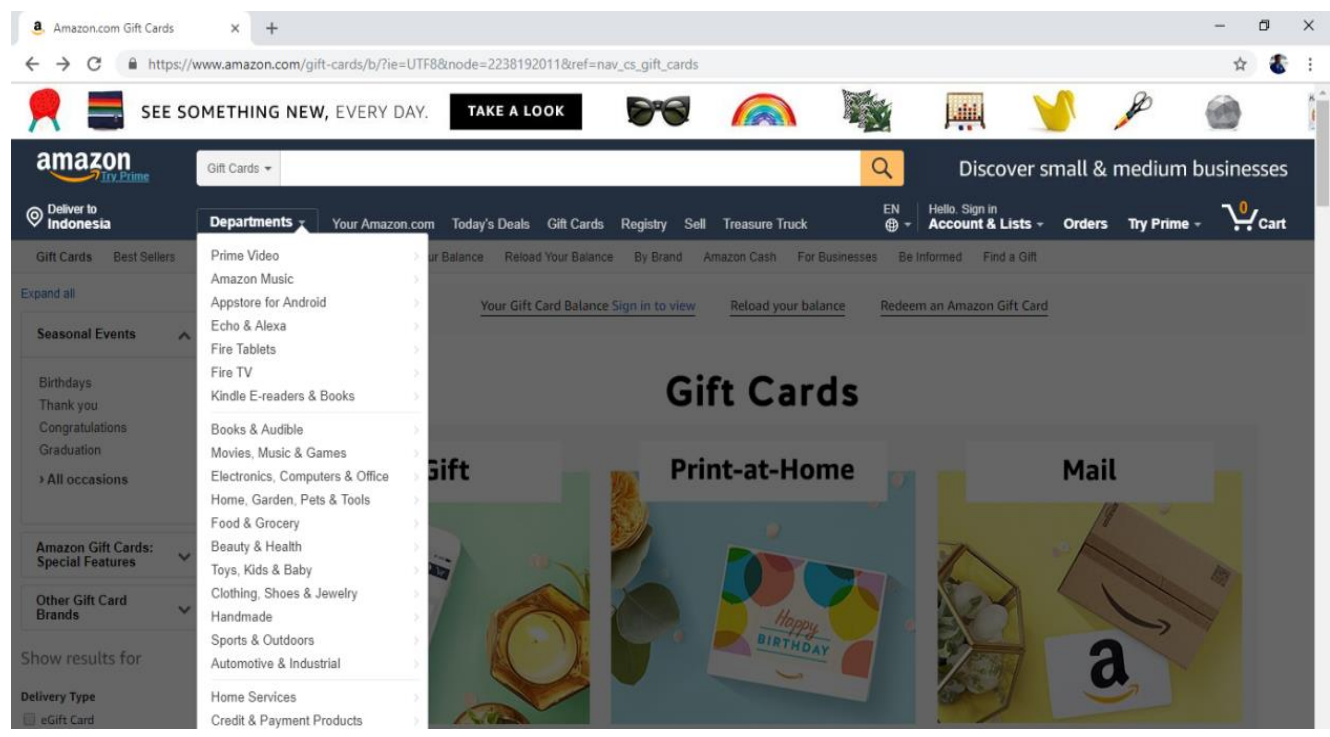

Fig. 3. Strategy E-Business. This figure was adopted from amazon.com on July 17, 2018. 


\section{Alibaba.com}

Figure 4. Alibaba.com design was a Chinese nuance and culture. But the more the company develops, the design that is not applied now to follows the trend of the modern, simple and adventurous nuance. This indicates that Alibaba is now an advanced company and has managed to sell Chinese products to the world.

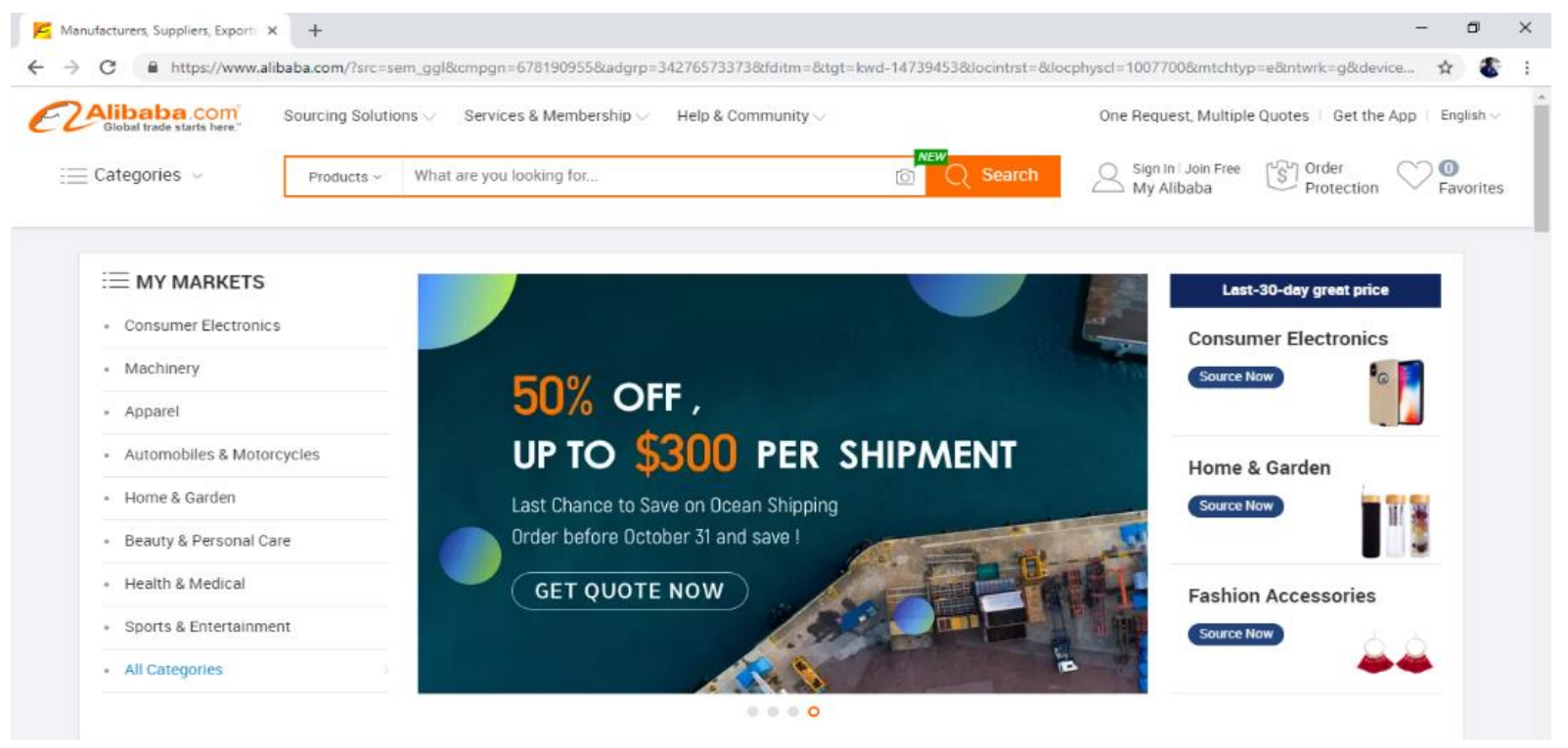

Figure 4. Form design. This figure was adopted from alibaba.com on July 17, 2018.

Figure 5. Unlike Amazon.com, the E-Business business strategy is not to buy products the company sells directly, but only to bridge between producers and consumers around the world which is more efficient because the products come directly from large and small producers. With this strategy, the company will save operational costs such as warehouse operating costs. According to the Chief Executive Officer Alibaba Group, Daniel Zhang said that the role of EBusiness helped in expanding the market so that it could increase revenue margins by $93 \%$ and earn a profit of USD10.45 Billion. 


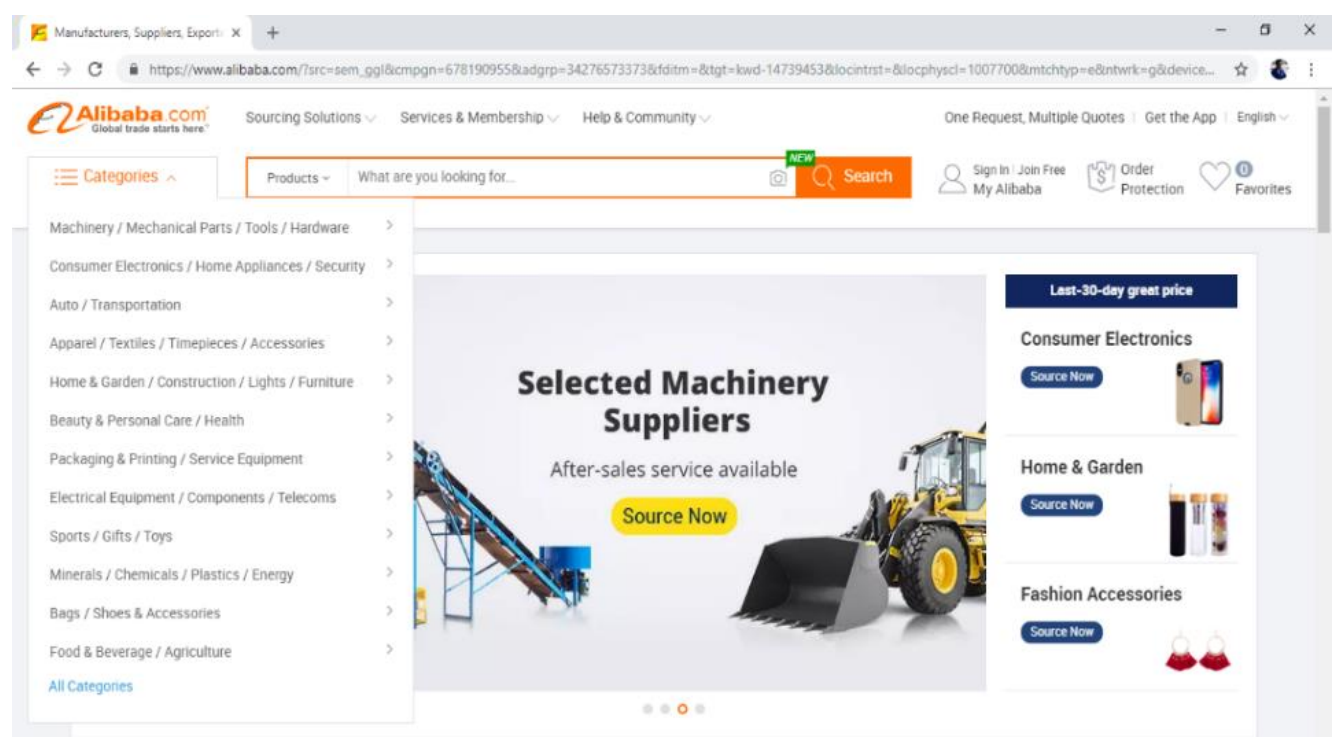

Fig. 5. Strategy E-Business. This figure was adopted from alibaba.com on July 17, 2018.

3. Shopee

Figure 6. In its design, Shopee follows a growing trend, matching orange and white colors that are expected to make its customers happier to shop by lifting the "simple and friendly" elements and connecting between sellers, buyers and admin on daily basis.

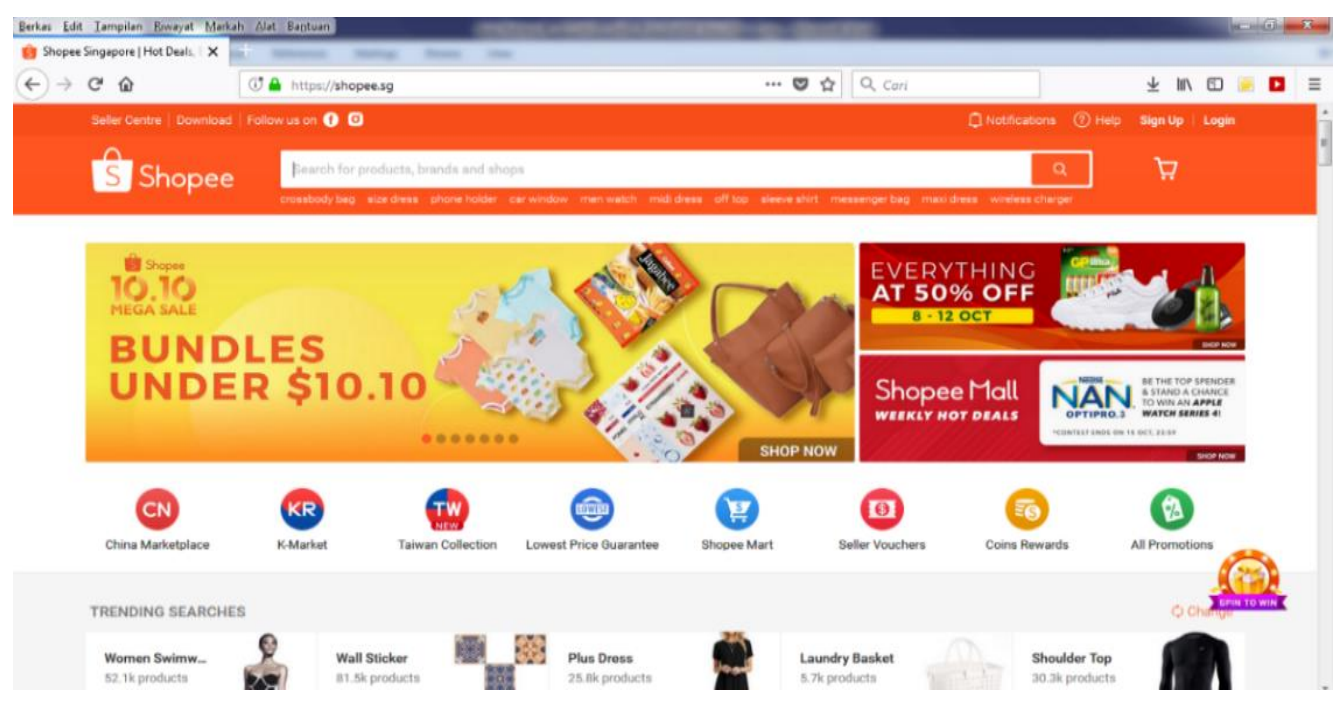

Fig. 1. Form Design Shopee. This figure was adopted from shopee.com on July 17, 2018.

Figure 7. In addition to focusing the market to women in all ages. Shopee carries out the latest strategy to attract the attention of many people by pampering buyers such as free delivery programs, flash sale, rocking shopee, and products that are guaranteed original. According to 
CEO Sea Ltd. Shopee has served 244 million orders, $40 \%$ of which are transaction in Indonesia and revenues earned amounted to USD 164.5 million or grew $73 \%$ in 2017.

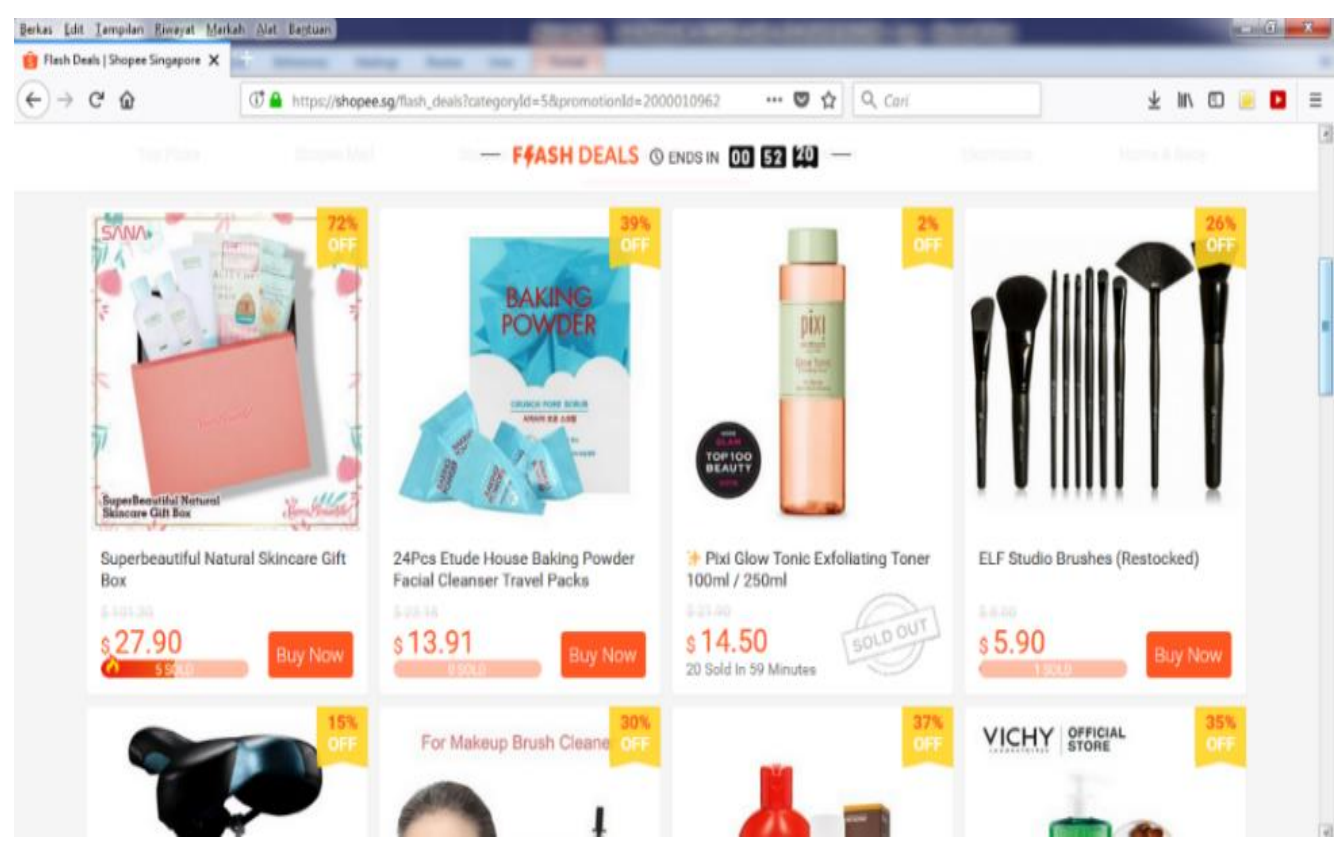

Figure 7. Strategy E-Business Shopee. This figure was adopted from shopee.com on July 17, 2018.

Figure 8. According to a survey made by Indonesian Internet Service Providers in 2017, the number of internet users has reached 143.26 million people,equivalent to $54.68 \%$ of Indonesia's population. From this data, Semuel hopes the survey to be useful for those in need especially entrepreneurs in Indonesia. 


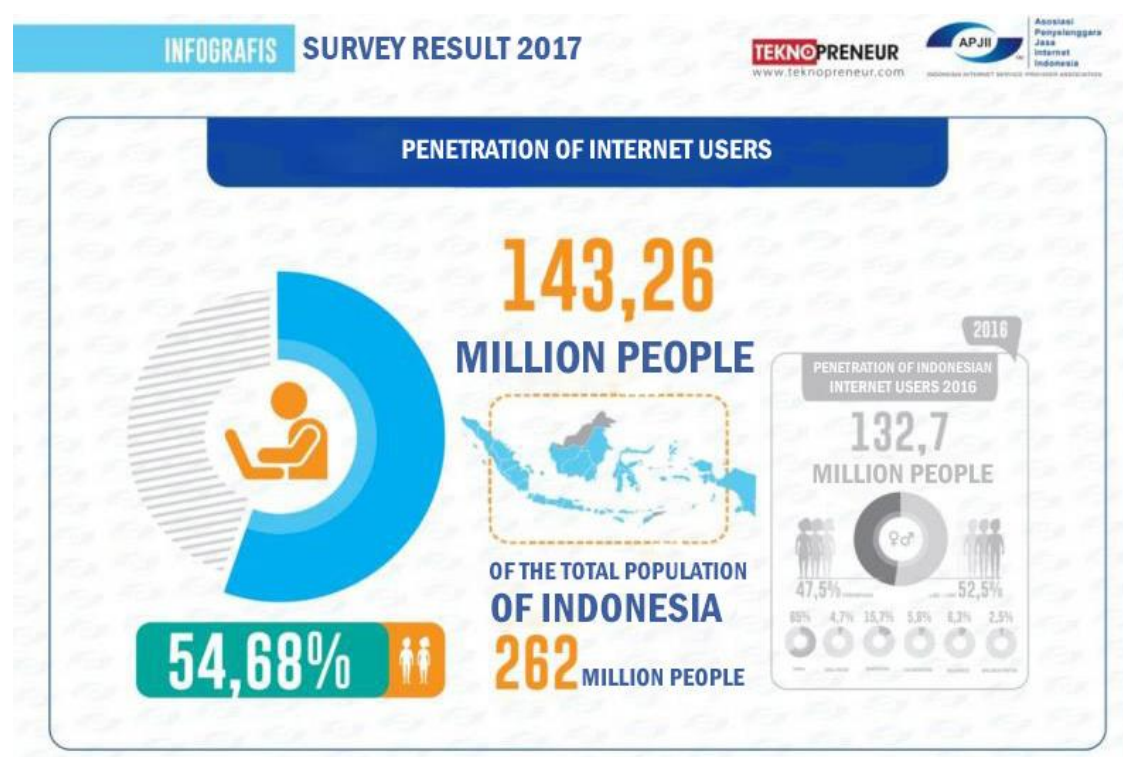

Fig. 8. Survey APJII on internet user in Indonesia

Creative entrepreneurs are required to be observant in achieving long-term business opportunities. In business world competition, the developing companies can only rely on management strategies. Companies that follow technological developments is said to be superior in their field. In addition, sales and purchase transactions are undergoing modernization, no longer using offline or traditional systems but have explored the virtual world of technology, one of which is E-business.

If the entrepreneur utilizes E-Business as a medium of competition and is creative in his management strategy. hence, it can be ascertained that E-Business will provide many advantages such as helping to expand market share both internationally and nationally, fostering trust in corporate loyalty, establishing cooperation with vendors and business partners or to maximize the level of customer satisfaction and also help in achieving positive image among the society. E-Business in the company will also reduce its operating costs, this is because EBusiness provides virtual storage for data, access information on distribution of goods, and can manage employee productivity efficiently and effectively.

\section{Conclusion}

Technological advances provide opportunities for entrepreneurs to always be creative and innovative so they can compete with similar companies both locally and internationally. For example, the utilization of E-Business technology which provides an important role in managing the company's strategy both operational and marketing. Entrepreneurs who utilize information technology in their operational activities will help create responsiveness to customers, faster and easier in the transaction, transparent and flexible to business systems, keeping up with modernity, improving their excellence in competition, and gaining more profit. Therefore, EBusiness is very effective and efficient for consumers or suppliers who need information about the product data offered, because in E-business has a real-time information exchange system. Also, E-Business has an important role in improving quality, company performance, operational productivity and has a positive image. 


\section{Acknowledgements}

Thanks to those who have provided insight into an entrepreneur so as to facilitate and assist in the preparation of the paper papers in accordance with international standards. As well as to colleagues who have helped provide advice on this paper.

\section{References}

[1] Hu, H.,Huang, T., Zeng, Q.,\& Zhang, S. : The Role of instutional entrepreneurship in building digital ecosystem : A case study of Red Collar Group (RCG). Internasional Journal of Information Manajement,36(3), 496-9. (2016).

[2] Al Omoush, K. S., Al-Qirem, R. M., \& Al Hawatmah, Z. M. : The degree of e-business entrepreneurship and long-term sustainability: an instutional perspective.Information Systems and e-Business Manajement, 16(1),22-56. (2018).

[3] Souza,E. M. D., \& Batista, P. C. D. S. : Strategic Antecedents and Consequents For The Performance of E-Business Companies. BBR. Brazilian Business Review,14(1), 59 85. (2017).

[4] Benitez-Amado, J., Ray, G. : Introducing IT- Enabled Business Fexibility and IT Integration in The Acquirer's M \& A Performance Equation. Thirty Third International Conerence on information Systems, 12, 1-21. Orlando, Florida, USA. (2012).

[5] Soegoto, E. S. : Euntrepreneurship :Menjadi Pebisnis Ulung. Jakarta, Indonesia : Kompas Gramedia. 4, 256-87. (2014).

[6] Benitez-Amado, J., Llorens-Montes, F. J., \&Fernandez-Perez, V. : The relationship between IT infrastructureleveraging, talent management and operational sustainability, and their effects onthe business value of the operations strategy. Proceedings of the nineteenth AmericasConference on Information Systems, 5, 1-8. Chicago, Illinois, USA. (2013).

[7] Karimi-Alaghehband, F., \&Rivard, S. : Air Canada : Flying High with Information Technology. Internasional Journal of Case Studies in Management,12(2), 1-20 HEC045. (2014).

[8] Benitez-Amado, J., Llorens-Montes, F. J., \&Fernandez-Perez, V. : IT impact on talent management and operationalenvironmental sustainability. Information Technology and Management, 16(3), 207-20. (2015).

[9] Aral, S., Brynjolfsson, E., \& Van Alstyne, M. : Information, technology, and information worker productivity. Information System Research., 23(3-part-2), 849-67. (2012).

[10] Handarkho, Y. D., Suryanto, T. R., Dewi, F. K. S., \& Julianto, E. : Penerapan Strategi E-Business untuk meningkatkan keunggulan kompetitif dari Usaha Mikro Kecil Menengah di Indonesia (Studi Kasus Trooper Electronik Yogyakarta). Jurnal Buana Informatika, 8(4), 201-12. Indonesia. (2017).

[11] Earl, M. J. : Evolving the e-business. Business Strategy Review, 11(2), 33-8. (2000).

[12] McCormack, K. P., \& Johnson, W. C. : Business process orientation: Gaining the ebusiness competitive advantage. CRC Press. (2001). 